J-DEPACE, Volume 3, Nomor 2, Desember 2020, Hal 240-249

Tersedia online di :http://jurnal.lpmiunvic.ac.id/index.php/jpkm

\title{
PEMANFAATAN LAHAN PEKARANGAN SELAMA PANDEMI COVID-19 DI KAMPUNG MALAGUFUK KABUPATEN SORONG
}

\author{
Charliany Hetharia ${ }^{1 *}$, Lanny Wattimena ${ }^{2}$ \\ Yerrynaldo Loppies ${ }^{3}$, Berti Pakaila ${ }^{4}$, Wiesje Ferdinandus ${ }^{5}$ \\ Program Studi Peternakan, Program Studi Kehutanan, Program Studi Ekonomi Pembangunan, \\ Program Studi Administrasi Publik, Universitas Victory Sorong \\ ${ }^{1}$ janethnadin270416@gmail.com *, ${ }^{2}$ lannywattimena@gmail.com , \\ ${ }^{3}$ jhay.loppies@gmail.com , ${ }^{4}$ berthipakaila@gmail.com ${ }^{5}$ wiesjeferdinandus@gmail.com
}

\begin{abstract}
ABSTRAK
Pandemi COVID-19 yang sedang terjadi sekarang ini, membuat masyarakat mengisolasi diri agar terhindar dari bahaya COVID-19. Untuk tetap menjaga diri dan keluarga, masyarakat harus mempersiapkan ketersediaan pangan secara mandiri dengan memanfaatkan lahan pekarangan rumah, salah satu bentuk pemanfaatan tersebut adalah tanaman seperti sayuran. Di Kampung Malagufuk Kabupaten Sorong sudah ada masyarakat yang memanfaatkan lahan pekarangan rumahnya, namun belum maksimal. Kegiatan penyuluhan ini bertujuan untuk mendorong serta memberi motivasi agar dapat mengoptimalkan lahan pekarangan rumah dalam membudidayakan tanaman pangan sesuai dengan luasan lahan pekarangan dan komoditas yang dapat ditanamami. Lahan pekarangan yang dimanfaatkan merupakan suatu wujud pemenuhan ketersediaan pangan keluarga yang juga daiharapkan dapat meningkatkan perekonomian kelaurga selama pandemic COVID-19. Metode pelaksanaan yang digunakan yaitu pengamatan, dan penyuluhan. Hasil yang dicapai dari penyuluhan ini adalah yaitu masyarakat memahami dan mengerti tentang pemanfaatan laha pekarangan untuk budidaya sayuran, yang akan meningkatkan kemampuan dan keterampilan alam pemanfaatan lahan pekarangan rumah mereka guna pemenuhan kebutuhan pangan keluarga sekaligus membantu pemenuhan ketersediaan pangan dan perekonomian keluarga.
\end{abstract}

Kata kunci: Pemanfaatan, pekarangan, Kampung Malagufuk 


\section{ABSTRACT}

The current COVID-19 pandemic has forced people to isolate themselves to avoid the dangers of COVID-19. To maintain themselves and their families, the community must prepare food availability independently by utilizing the land in the yard of the house, one form of utilization is plants such as vegetables. In Malagufuk Village, Sorong Regency, there are already people who use their home yards, but this has not been maximized. This outreach activity aims to encourage and provide motivation in order to optimize the yard of the house in cultivating food crops in accordance with the area of the yard and the commodities that can be planted. The yard land that is used is a form of fulfilling the availability of family food which is also expected to improve the family economy during the COVID-19 pandemic. The implementation method used is observation, and counseling. The results achieved from this counseling are that the community understands and understands the use of yard land for vegetable cultivation, which will increase the natural abilities and skills of using their home yard land to meet family food needs while helping to fulfill food availability and the family economy.

Keywords: Utilization, yard, Malagufuk Village.

\section{PENDAHULUAN}

Ditengah pandemi COVID-19 yang terjadi sekarang ini, tingkat ketakutan dan kecemasan masyarakat semakin tinggi untuk melaksanakan aktifitas diluar rumah, ditambah lagi dengan semakin meluas penyebaran virus ini, maka masyarakat dihimbau untuk tetap berada di rumah dan keluar rumah hanya untuk keperluan yang mendesak saja sehingga bisa memutuskan penyebaran virus COVID-19. Masyarakat yang sudah terbiasa bekerja diluar rumah ketika diperhadapkan dengan kondisi, selama pandemi ini pastilah timbul rasa jenuh dan bosan. Untuk mengatasi kejenuhan selama pandemic COVID-19. adalah dengan memanfaatkan lahan pekarangan untuk budidaya tanaman sayur sebagai salah satu kebutuhan pokok guna mendukung pemenuhan kebutuhan pangan keluarga.

Dampak lainnya dari pademi ini adalah menurunnya pendapatan masyarakat sehingga terjadikesenjangan ekonomi dalam memenuhi ketersediaan pangan. Salah satu bentuk pemenuhan ketersediaan pangan tersebut adalah pemanfaatan lahan pekarangan. Menurut Nurwati dkk (2015) pemanfaatan lahan pekarangan juga merupakan alternatif dalam mewujudkan kemandirian rumah tangga. Pendapat ini mendukung penyataan dari Ashari dkk (2012) yang menjelaskan bahwa dengan memanfaatkan fungsi pekarangan akan mendatangkan banyak manfaat diantaranya apotek dan lumbung hidup. 
Seiring dengan pemanfaatan lahan pekarangan ini, Kementerian Pertanian Republik Indonesia juga memiliki satu strategi yaitu mengoptimalkan lahan pekarangan dengan budidaya tanaman pangan untuk pemenuhan kebutuhan keluarga guna mendukung ketersediaan pangan sehingga dapat meningkatkan imunitas keluarga baik dari segi kuantitas, kualitas, keragaman maupun kemudahan memperoleh kebutuhan pangan tersebut. Lahan pekarangan bisa dimanfaatkan secara baik sebagai sumber penyedia pangan baik bahan pangan nabati maupun hewani. Sumber pangan nabati yang bisa diusahakan di lahan pekarangan antara lain tanaman holtikultura, tanaman rempah dan obat, sedangakan sumber pangan hewani yang bisa diusahkan adalah ternak ayam dan ikan.

Pemilihan sumber pangan yang akan dikembangkan sangat tergantung pada luas lahan pekarangan serta bahan pendukung yang tersedia. Semakin luas pekarangan maka semakin banyak jenis tanaman pangan yang bisa dikembangkan. Rumah dengan pekarangan yang sempit maupun tanpa pekarangan, dapat melakukan budidaya tanaman dengan metode budidaya yang disesuakan dengan luas pekarangan. Prinsip pemanfaatan lahan pekarangan harus memperhatikan aspek estetika sehingga pekarangan menjadi lebih indah dan nyaman. Tanaman yang dibudidaya harus diatur sedenikian rupa sehingga tidak mengurangi kenyamanan dan keindahan pekarangan rumah.

Tanaman yang akan dibudidayakan pada pekarangan rumah adalah tanaman yang memenuhi kebutuhan gizi dan pangan keluarga serta merupakan sumber pangan lokal, karena pangan lokal bisa beradaptasi dengan lingkungan lingkungan (iklim, kekeringan, dan lebih tahan terhadap hama penyakit tanaman). Tanaman yang memiliki prospek untuk dikembangkan pada pekarangan adalah tanaman hortikultura (sayur, buah-buahan, toga/biofarmaka/obat-obatan), serta ternak dan ikan. Pemilihan tanaman disesuaikan dengan luas lahan, kebutuhan akan pangan serta keadaan lingkungan.

Berdasarkan hasil pengamatan dan wawancara yang dilakukan di Kampung Malagufuk Kabupaten Sorong, semua masyarakatnya memiliki pekarangan rumah namun belum dimaksimalkan dengan baik. Padahal lahan pekarangan jika dimanfaatkan secara optimal untuk ditanami berbagai macam tanaman seperti sayuran dengan berbagai cara menanam maka akan dirasakan manfaatnya. Melalui penyuluhan tentang pemanfaatan pekarangan rumah dapat 
memberikan dorongan serta motivasi bagi masyarakat betapa pentingnya memanfaatkan pekarangan rumah untuk memenuhi kebutuhan pangan.

\section{MASALAH}

Melihat pandemi COVID-19 yang belum dapat dipastikan berakhir dan untuk dapat mengamankan ketersedian pangan guna pemenuhan kebutuhan pangan keluarga, maka keluarga harus dapat memanfaatkan lahan pekarangan yang dimiliki dengan optimal sehingga dapat memperkuat ketahanan pangan keluarga agar dapat meningkatkan ketahanan dan kemandirian pangan kampung terutama pada masa pandemi COVID-19. Berdasarkan hasil pengamatan dan wawancara yang dilakukan di Kampung Malagufuk Kabupaten Sorong, hal lain yang ditemukan yaitu semakin meningkatnya harga kebutuhan pokok berbanding terbalik dengan penghasilan yang diperoleh selama masa pandemi, sehingga dengan memanfaatkan lahan pekarangan dapat mengurangi biaya hidup rumah tangga sehingga secara tidak langsung dapat membantu ekonomi keluarga.

\section{METODE PELAKSANAAN}

Metode pelaksanaan kegiatan ini adalah wawancara, observasi dan sosialisasi. Sosialisasinya berupa penyampaian materi kepada masyarakat tentang pemanfaatan lahan pekarangan dengan jenis tanamana pangan dan teknik penanaman yang beragam. Kegiatan sosialisasi ini dilaksanakan pada tanggal 24 - 21 November 2020 bertempat di kampung Malgufuk Kabupaten Sorong. Kegiatan ini diikuti oleh masyarakat Kampung Malgufuk Kabupaten Sorong.
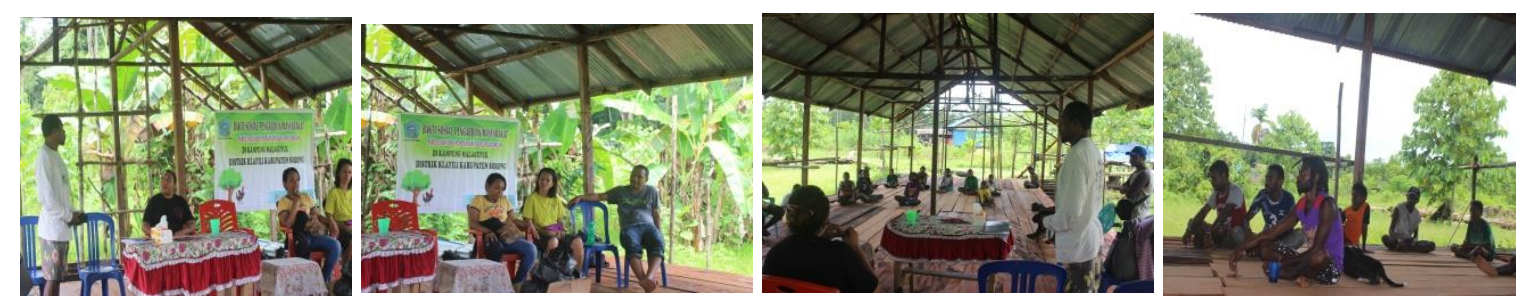

Gambar 1. Dokumentasi Penelitian 


\section{HASIL DAN PEMBAHASAN}

Pemanfaatan lahan pekarangan rumah sangat berguna untuk penyediaan bahan pangan selama masa pandemi. Budidaya tanaman sayuran sangat membantu meringankan pengeluaran serta menambah pendapatan selama masa COVID-19. Untuk itu dilakukan sosialisasi kepada masyarakat Kampung Malgufuk Kabupaten Sorong. Diharapkan dengan adanya sosialisasi ini, masyarakat dapat mengoptimalisasikan lahan pekarangan dalam menyediakan pangan bagi keluarga serta dapat meningkatkan pengetahuan, keterampilan, kesadaran untuk memanfaatkan lahan pekarangan yang masih kosong selama masa pandemic ini.

Pemanfaatan lahan pekarangan sebagai sumber pangan keluarga, sangat penting di masa pandemic COVID-19 ini. Budidaya tanaman holtikultura akan sangat membantu pengeluaran masyarakat terdampak COVID-19. Sebelum masu pada proses budidaya, masyarakat perlu mengetahui tentang kategori luasan lahan pekarangan. Mardiharini, dkk (2013), menjelaskan bahwa berdasarkan luasannya lahan pekarangan di perkotaan dan pedesaan dibagi menjadi 4 strata (Tabel 1).

Tabel 1. Pembagian Lahan Pekarangan di Perkotaan dan Pedesaan Berdasarkan Luasannya

\begin{tabular}{|c|c|c|c|}
\hline Strata & Kategori & Perkotaan & Pedesaan \\
\hline I & Sangat sempit & $\begin{array}{c}\text { Tipe Rumah } 21 \\
\left(\text { Luas Tanah } 36 \mathrm{~m}^{2}\right)\end{array}$ & Tanpa Pekarangan \\
\hline II & Sempit & $\begin{array}{c}\text { Tipe rumah } 36 \\
\left(\text { Luas Tanah } \pm 72 \mathrm{~m}^{2}\right)\end{array}$ & $\begin{array}{c}\text { Pekarangan sempit } \\
\left(<120 \mathrm{~m}^{2}\right)\end{array}$ \\
\hline III & Sedang & $\begin{array}{c}\text { Rumah tipe } 45 \\
\left(\text { Luas Tanah } \pm 90 \mathrm{~m}^{2}\right)\end{array}$ & $\begin{array}{c}\text { Pekarangan sedang } \\
\left(120-400 \mathrm{~m}^{2}\right)\end{array}$ \\
\hline IV & Luas & $\begin{array}{c}\text { Rumah tipe } 54 \text { atau } 60 \\
\left(\text { Luas Tanah } \pm 120 \mathrm{~m}^{2}\right)\end{array}$ & $\begin{array}{c}\text { Pekarangan luas } \\
\left(>400 \mathrm{~m}^{2}\right)\end{array}$ \\
\hline
\end{tabular}

Tabel 1, menjelaskan bahwa keterbatasan lahan pekarangan tidak menjadi halangan untuk budidaya tanaman di rumah. Rumah yang tidak memiliki pekaranganpun masih dapat melakukan kegiatan budidaya tanaman, dengan memperhatikan cara dan metode tentang perkembangan teknologi budidaya tanaman. Cara dan metode yang dapat digunakan pada rumah tanpa pekarangan dengan memperhatikan perkembangan teknologi budidaya 
tanaman antara lain teknik budidaya vertikultur, teknik budidaya menggunkaan media tanam seperti pot maupun polybag, serta sistem hidroponik.

Teknik dan media yang dapat digunakan pada lahan pekarangan antara lain:

1. Pot dan polybag

Pot dan polybag merupakan media penanaman yang sering digunakan untuk bertanam karena dapat menghemat lahan pekarangan. Polybag biasanya berwarna hitam, berbahan plastik, dan memiliki lubang pada dasar maupun didinding polybad yang berfungsi sebagai tempat sirkulasi air. Polybag mudah digunakan dan harganya terjangkau. Menurut Pasir dan Hakim (2014), sayuran dan buah yang bisa ditanam pada polibag antara lain cabai, tomat, sawi dan jenis sayuran lainnya

2. Vertikultur.

Teknik vertikultur biasanya memanfaatkan bidang vertikal yang bertingkat sebagai media untuk bercocok tanam. Teknik ini sering dilakukan karena terbatasnya lahan pekarangan. Cara membuat vertikultur cukadalah dengan membuat kerangka berbentuk rangkaian rak yang disusun, biasanya menggunakan talang air, botol bekas, kaleng bekas, atau bambu. Media tanam untuk teknik vertikultur yaitu campuran kompos, sekam bakar dan tanah. Vertikultur dapat ditempatkan dimana saja dengan memperhatikan sinar matahari, sebaiknya semua tanaman yang menggunakan teknik ini harur terkena sinar matahari (Soleh dkk, 2020). Selanjutnya menurut Soleh dkk (2020) teknik vertikultur, sangat cocok untuk jenis tanaman seperti sawi, kucai, kangkung, bayam, caisim, selada bokor, seledri dan bawang daun.

3. Hidroponik

Hidroponik merupakan lahan budidaya tanaman dengan air sebagai media tanam pengganti tanah. Teknik ini dapat dimanfaatkan untuk lahan pekarangan yang sempit. Dengan menggunakan sistem hidroponik, sayuran yang dapat ditanam antara lain selada, sawi, tomat, cabai, brokoli, dll. Terkadang ukuran sayuran tidak sama antara yang ditanam di tingkat atas dan bawah pada model hidroponik. Tanaman bagian atas akan menerima, sedangkan tanaman yang berada pada tingkat bawahnya menerima sisa nutrisi yang dialirkan ke bawah (Pujiastuti, 2017). 
Selain teknik dan media yang dapat digunakan pada lahan pekarangan, masyarakat juga perlu mengetahui tentang jenis komoditas yang bisa dikembangkan berdasarkan pembagian lahan pekarangan di perkotaan dan pedesaan menurut luasannya seperti pada Tabel 2. Tabel 2, menjelaskan tentang model budidaya berdasarkan teknik dan media yang telah dijelaskan sebelumnya dengan memperhatikan jenis komoditas disesuaikan dengan pembagian lahan pekarangan di perkotaan dan pedesaan menurut luasannya

Tabel 2. Jenis Komoditas Berdasarkan Pembagian Lahan Pekarangan Di Perkotaan Dan Pedesaan Menurut Luasannya

\begin{tabular}{|c|c|c|}
\hline Kelompok Lahan & Model Budidaya & Jenis Komoditas \\
\hline $\begin{array}{l}\text { - Tipe Rumah 21 } \\
\left(\text { Luas Tanah } 36 \mathrm{~m}^{2}\right) \\
\text { - Tanpa pekarangan }\end{array}$ & $\begin{array}{l}\text { - Vertikultur } \\
\text { (bertingkat, gantung } \\
\text { atau tempel) } \\
\text { - Pot/Polybag/ Wadah } \\
\text { dari barang bekas }\end{array}$ & $\begin{array}{l}\text { - Sayuran daun : sawi, kucai, } \\
\text { pakcoy, kangkung, bayam , } \\
\text { kemangi, caisim, selada, } \\
\text { seledri, daun bawang. } \\
\text { - Sayuran Buah: cabai, terong, } \\
\text { tomat, mentimun } \\
\text { - Toga: serai, kencur, antanan, } \\
\text { gempur batu, daun jintan, } \\
\text { sambiloto, jahe, kunyit, temu } \\
\text { lawak, kumis kucing, sirih } \\
\text { hijau/merah, pegagan, lida } \\
\text { buaya. }\end{array}$ \\
\hline $\begin{array}{ll}\text { - } & \text { Tipe rumah 36(Luas } \\
\left.\text { Tanah } \pm 72 \mathrm{~m}^{2}\right) \\
\text { - } & \text { Pekarangan sempit } \\
\left(<120 \mathrm{~m}^{2}\right)^{* * *} & \end{array}$ & $\begin{array}{l}\text { - Vertikultur } \\
\text { (bertingkat, gantung } \\
\text { atau temple) } \\
\text { - Pot/Polybag/ Wadah } \\
\text { dari barang } \\
\text { bekas/Tanam } \\
\text { langsung di lahan } \\
\text { - Kandang* } \\
\text { - Kolam Terpal }\end{array}$ & $\begin{array}{l}\text { - Sayuran daun : sawi, kucai, } \\
\text { pakcoy, kangkung, bayam , } \\
\text { kemangi, caisim, selada, } \\
\text { seledri, daun bawang. } \\
\text { - Sayuran Buah: cabai, terong, } \\
\text { tomat, mentimun } \\
\text { - Toga: serai, kencur, antanan, } \\
\text { gempur batu, daun jintan, } \\
\text { sambiloto, jahe, kunyit, temu } \\
\text { lawak, kumis kucing, sirih } \\
\text { hijau/merah, pegagan, lida } \\
\text { buaya. } \\
\text { - Buah : papaya, jeruk nipis, } \\
\text { jambu } \\
\text { - Ternak: ayam buras* } \\
\text { - Pemeliharaan } \\
\text { lele/gurami/nila/ikan lokal }\end{array}$ \\
\hline
\end{tabular}




\begin{tabular}{|c|c|c|}
\hline $\begin{array}{l}\text { - Tipe Rumah } 45 \\
\text { (luas tanah } \pm 90 \mathrm{~m}^{2} \\
\text { ). } \\
\text { - Pekarangan sedang } \\
\left(120-400 \mathrm{~m}^{2}\right)^{* *}\end{array}$ & $\begin{array}{l}\text { - Pot/Polybag/ Wadah } \\
\text { dari barang bekas } \\
\text { Tanam langsung di } \\
\text { lahan } \\
\text { - Bedengan/ Tanam } \\
\text { langsung di lahan } \\
\text { - Kandang* } \\
\text { - Kolam Terpal* } \\
\text { - Multistrata }\end{array}$ & $\begin{array}{l}\text { - Sayuran daun: sawi, kucai, } \\
\text { pakcoy, kangkung, bayam, } \\
\text { kemangi, caisim, selada, } \\
\text { seledri, daun bawang. } \\
\text { - Sayuran Buah: cabai, terong, } \\
\text { tomat, mentimun } \\
\text { - Toga: serai, kencur, antanan, } \\
\text { gempur batu, daun jintan, } \\
\text { sambiloto, jahe, kunyit, temu } \\
\text { lawak, kumis kucing, sirih } \\
\text { hijau/merah, pegagan, lida } \\
\text { buaya. } \\
\text { - Buah: papaya, jeruk nipis, } \\
\text { jambu } \\
\text { - Kacang-kacangan } \\
\text { - Tanaman pangan: ubi jalar, } \\
\text { talas, Umbi-umbian lainnya } \\
\text { - Ternak : ayam buras } \\
\text { - Pemeliharaan } \\
\text { lele/gurami/nila/ ikan lokal * }\end{array}$ \\
\hline $\begin{array}{l}\text { - Rumah tipe } 54 \text { atau } \\
60 \text { (luas tanah } \pm 120 \\
\left.\mathrm{~m}^{2}\right) \text {. } \\
\text { - Pekarangan luas } \\
\left(>400 \mathrm{~m}^{2}\right)^{* *}\end{array}$ & $\begin{array}{l}\text { - Pot/Polybag/ Wadah } \\
\text { dari barang bekas } \\
\text { Tanam langsung di } \\
\text { lahan } \\
\text { - Bedengan/ Tanam } \\
\text { langsung di lahan } \\
\text { - Kandang } \\
\text { - Kolam Terpal } \\
\text { - Multistrata* }\end{array}$ & $\begin{array}{l}\text { - Sayuran daun : sawi, kucai, } \\
\text { pakcoy, kangkung, bayam , } \\
\text { kemangi, caisim, selada, } \\
\text { seledri, daun bawang. } \\
\text { - Sayuran Buah: cabai, terong, } \\
\text { tomat, mentimun } \\
\text { - Toga: serai, kencur, antanan, } \\
\text { gempur batu, daun jintan, } \\
\text { sambiloto, jahe, kunyit, temu } \\
\text { lawak, kumis kucing, sirih } \\
\text { hijau/merah, pegagan, lida } \\
\text { buaya. } \\
\text { - Buah : papaya, jeruk nipis, } \\
\text { jambu } \\
\text { - Kacang-kacangan } \\
\text { - Tanaman pangan: ubi jalar, } \\
\text { talas, Umbi-umbian lainnya } \\
\text { - Ternak : ayam buras, kambing, } \\
\text { domba* } \\
\text { - Pemeliharaan } \\
\text { lele/gurami/nila/ ikan lokal * }\end{array}$ \\
\hline
\end{tabular}

**) perdesaan

*) dibudidayakan di perdesaan 


\section{Pemanfaatan Lahan Pekarangan Selama Pandemi Covid-19 Di Kampung Malagufuk Kabupaten Sorong}

Budidaya tanaman pangan dengan memanfaatkan lahan pekarangan sesuai luasannya dimaksudkan agar dapat memenuhi kebutuhan pangan keluarga selama masa pandemi sehingga dapat membantu mengurangi pengeluaran masyarakat terdampak COVID-19. Pangan sehat yang diproduksi sendiri oleh masyarakat sendiri diharapkan dapat membantu perekonomian keluarga. Kegiatan bertani yang memanfaatkan lahan pekarangan dapat juga berdampak pada pemanfaatan waktu dan tenaga selama berada di rumah, sekaligus menyehatkan pikiran serta menciptakan lingkungan yang hijau. Dengan adanya kegiatan penyuluhan ini sangat membatu masyarakat Kampung Malagufuk, hal ini terlihat dari apresiasi masyarakat dalam mengikuti kegiatan ini. Dengan tetap memperhatikan protokol kesehatan masyarakat Kampung Malagufuk sangat antusian mengikuti kediatan dimaksud. Masyarakat menjadi lebih teredukasi untuk memanfaatkan lahan pekarangan rumah mereka guna pemenuhan kebutuhan pangan keluarga sekaligus membantu pemenuhuan ketersediaan pangan dan perekonomia keluarga.

\section{KESIMPULAN}

Usaha untuk mencukupi ketersediaan pangan selama masa pandemi Covid-19 adalah pemanfaatan lahan pekarangan. Lahan pekaranga rumah yang dimanfaatkan dengan budidaya sayuran, akan meningkat kemampuan dan keterampilan masyarakat dalam pemanfaatan lahan pekarangan rumah mereka guna pemenuhan kebutuhan pangan keluarga sekaligus membantu pemenuhuan ketersediaan pangan dan perekonomian keluarga.

\section{UCAPAN TERIMA KASIH}

Kegiatan pengabdian kepada masyarakat ini terlaksana berkat dukungan Fakultas Ilmu Pertanian dan lingkungan serta Lembaga Penelitian dan Pengabdian Masyarakat Universitas Victory Sorong

\section{DAFTAR PUSTAKA}

Ashari, Saptana, Purwanti, TB. (2012). Potensi dan Prospek Pemanfaatan Lahan Pekarangan Untuk Mendukung Ketahanan Pangan. Forum Penelitian Agro Ekonomi, 30 (1): 13-30.

Ayuningtyas, C.E., Jatmika, S. E. D. 2002. Pemanfaatan Lahan Pekarangan untuk Meningkatkan Gizi Keluarga. Yogyakarta: K-Media. 
Mardiharini, Mesti., Purnomo, Sudarmadi., Hanifah, Vyta., Andrianyta, Harmi. 2013. Petunjuk Pelaksanaan Pengembangan Model Kawasan Rumah Pangan Lestari (m-KRPL) dan sinergi Program Tahun 2013. Badan Litbang Pertanian. Jakarta

Nurwati, N., Surtinah, Amalia. (2015). Analisis Pemanfaatan Pekarangan untuk Mendukung Ketahanan Pangan di Kecamatan Rumbai Pesisir Kota Pekanbaru. Jurnal Ilmiah Pertanian, 11(2): 1-8.

Pasir S., Hakim, MS. (2014). Penyuluhan Penanaman Sayuran dengan Media Polibag. Jurnal Inov dan Kewirausahaan, 3(3): 159-163.

Pujiastuti, E. 2017. 29 Teknik Urban Farming. I. (Apriyani RN, ed) Depok: PT Trubus Swadaya.

Sismihardjo. (2008). Kajian agronomis tanaman buah dan sayuran pada struktur agroforestri pekarangan di wilayah Bogor, Puncak dan Cianjur (Studi kasus di DAS Ciliwung dan DAS Cianjur). Tesis. Program Studi Agronomi, Sekolah Pascasarjana. Institut Pertanian Bogor.

Soleh, Avi Nur., Billa Krisbiyanti, Jihan Ana Fahira, Tiara Wulandari. 2020. Upaya Pemanfaatan Lahan Pekarangan Rumah Untuk Budidaya Tanaman Sayuran Sebagai Penyedia Pangan Di Masa Pandemi covid-19 di Desa Panjunan RT 012 RW 002 Kec. Petarukan, Kab. Pemalang. KKN (Kuliah Kerja Nyata) Bersama Melawan Covid Universitas Negeri Semarang 